Article

\title{
Descendants of Hardship: Prevalence, Drivers and Scarring Effects of Social Exclusion in Childhood
}

\author{
J. Cok Vrooman ${ }^{1, *}$, Stella J. M. Hoff ${ }^{1}$ and Maurice Guiaux ${ }^{2}$ \\ ${ }^{1}$ The Netherlands Institute for Social Research|SCP, P.O. Box 16164, 2500 BD The Hague, The Netherlands; \\ E-Mails: c.vrooman@scp.nl (J.C.V.), s.hoff@scp.nl (S.J.M.H.) \\ ${ }^{2}$ Knowledge Centre, Dutch Institute for Employee Benefit Schemes, La Guardiaweg 94-114 (C-building), \\ 1043 DL Amsterdam, The Netherlands; E-Mail: maurice.guiaux@uwv.nl (M.G.) \\ * Corresponding author
}

Submitted: 1 July 2014 | In Revised Form: 22 December 2014 | Accepted: 28 January 2015 |

Published: 24 July 2015

\begin{abstract}
The social exclusion of children is problematic for two reasons. Young people typically inherit their marginal position from their family, and therefore cannot be held responsible for their hardship themselves; and social exclusion in childhood may affect their wellbeing and subsequent development, possibly leading to a "scarring effect" in later life. In this contribution we develop an instrument for measuring social exclusion among children. Social exclusion is regarded as a theoretical construct with four sub-dimensions: material deprivation, limited social participation, inadequate access to social rights, and a lack of normative integration. First we analyse data from a survey of 2,200 Dutch children, which contains a large set of social exclusion items. We applied nonlinear principal components analysis in order to construct a multidimensional scale. Measured in this way, the prevalence of social exclusion among children is $4.5 \%$. Boys and children living in large families are more likely to experience social exclusion than girls and children with few siblings. The parental level of education and dependency on social security benefits are also important driving factors of childhood social exclusion. Subsequently we investigate the scarring effect. Longitudinal administrative income and household data covering 25 years were combined with a new survey of just under 1,000 Dutch adults, a third of whom were poor as a child. The survey assessed their past and current degree of social exclusion, and their health and psychosocial development, educational career, past family circumstances, etc. In an absolute sense scarring turns out to have been limited during this period: a very large majority of those who were poor or excluded as a child are above the threshold values in adult life. However, the "descendants of hardship" are still more likely to be socially excluded as adults than people who grew up in more favourable conditions. A causal analysis suggests that low educational achievements are the main mediator of scarring risks.
\end{abstract}

\section{Keywords}

children; nonlinear principal components analysis; poverty; scarring effect; social exclusion

\section{Issue}

This article is part of the special issue "Indicators and Measurement of Social Inclusion", edited by Professor Peter Huxley (Bangor University, UK).

(C) 2015 by the authors; licensee Cogitatio (Lisbon, Portugal). This article is licensed under a Creative Commons Attribution 4.0 International License (CC BY).

\section{Introduction}

When social exclusion affects children, it tends to be regarded as a more serious social problem than when it occurs among adults. This may be partly a matter of principle on the part of policymakers, parents and the public at large. Typically, according to this view children cannot be held responsible for the social and cul- 
tural problems they experience, as these mostly reflect the marginal position of their families and the institutional deficiencies of their society. Thus, socially excluded children are not regarded as the agents of their own misery, but rather as descendants of the hardships imposed upon them by their social environment. In more practical terms, social exclusion of children is often considered problematic because it is assumed to generate negative consequences for personal development, social integration and status attainment. In the short run, marginalised children may be hampered in their cognitive, social and emotional development, they may lag behind at school, and they may be unable to build positive social relationships with their peers. Over a longer period of time, social exclusion during childhood is presumed to translate into school dropout and low educational attainment, high unemployment and benefit dependency, poor job prospects, lower incomes and delinquent behaviour, thus ensuring the reproduction of social exclusion from one generation to the next. This is not only a loss for adults who may experience "scarring effects" as a result of the hardships they encountered in early life, in the sense that poverty and social exclusion may persist throughout their life course and possibly have other unfavourable outcomes such as a low level of education, low labour participation rate and poor health. It may also be suboptimal from a collective point of view: society may be worse off if social exclusion during childhood translates into a more limited development of human capital and work skills, lower productivity and labour market participation, higher crime and unemployment rates, higher social expenditure, more social unrest and less social integration.

Starting from these social policy issues, the Netherlands Institute for Social Research/SCP conducted a large-scale research programme on childhood social exclusion which addressed the following research questions:

- How should social exclusion be conceptualised in the case of children?

- Is it possible to operationalise index measures for social exclusion among children which cover the general construct and the theoretical subdimensions?

- What is the current prevalence of social exclusion among children in the Netherlands; and what are the main short-term driving factors?

- Do "scarring effects" occur among adults who experienced poverty and social exclusion as a child?

In the next section we will first discuss some conceptual issues. We then present our data and methodology before turning to the empirical aspects: index construction and the short and long-term analysis of social ex- clusion. In the final section we summarise our conclusions.

\section{Conceptualising the Social Exclusion of Children}

In general terms social exclusion refers to people who experience an accumulation of disadvantage in the society in which they live. It may be regarded as a specific form of social inequality: socially excluded people lag behind in terms of what it takes to be a fully fledged member of society. Conceived in this way, social exclusion has been linked to people who fall behind structurally in terms of resources, such as migrants and the marginalised urban underclass (e.g., Lewis, 1969; Wilson, 1987), but also to cultural conflicts between insiders and outsiders in small communities (e.g., Elias \& Scotson, 1965). The retrenchment measures that many nations introduced with regard to social security and health care from the 1980s on (Levy, 2010; Pierson, 1996) led to a re-emergence of social exclusion as a policy theme, as these reforms made it more likely that vulnerable people would fall behind the rest of society. This may have been reinforced by the rise in migration, the growing importance of educational credentials in job allocation, and new information technologies that people with limited skills may not be able to master. In its Europe 2020 programme, the EU expressed the goal of reducing the number of people who are at risk of poverty or social exclusion (AROPE) by 20 million (European Commission, 2011). A monitoring instrument was developed for this purpose which combined relative poverty, severe material deprivation and work intensity at household level (Eurostat, 2014).

In their literature review, Jehoel-Gijsbers (2004) and Vrooman and Hoff (2013) point out that research into social exclusion among adults was mostly inspired by two theoretical schools: an Anglo-Saxon line and a French tradition (see also Fahey, 2010; Hills, LeGrand, \& Piachaud, 2002; Øyen, 1997; Pantazis, Gordon, \& Levitas, 2006; Room, 1997). The Anglo-Saxon tradition had its roots in the notion of "relative deprivation": the idea that people typically regard themselves as badly off or well-to-do compared to others they deem important (their reference group). This became a key tenet of American functionalist sociology (e.g., Merton \& Rossi, 1968), and in Britain it was a central element in the work of Runciman (1966) and Townsend (1979). This British school favoured an objective approach in terms of social indicators: it emphasised the empirical analysis of social exclusion, mainly regarded as a form of relative material deprivation. The French tradition, on the other hand, harks back to the work of Durkheim (1897), especially where he tries to explain suicide in terms of "anomie" (normlessness: a condition in which a society or community provides little moral guidance to its members). When unemployment rose in France during the 1970s and 1980s, and new social assistance 
legislation was introduced, the concept of social exclusion became a key issue in the French policy debate (cf., Paugam, 1996). Here the socio-cultural meaning of the term was stressed: social disintegration and an inability to maintain social relations. This was mostly linked to the demise of traditional solidarity at family and community level, and a lack of effective social rights on the part of the national state.

From this literature review Jehoel-Gijsbers (2004) and Vrooman and Hoff (2013) concluded that social exclusion theoretically relates to four different dimensions. Two of these are forms of socio-cultural exclusion, in line with the French tradition. Limited social participation means that people maintain few contacts with others, have small social networks, and show low social engagement. A lack of normative integration occurs when people fail to comply with the dominant norms and values of their community. Two other dimensions derive from the Anglo-Saxon tradition and may be labelled as structural-economic. Material deprivation implies that people experience certain deficits, which may be reflected in a lack of basic goods and services for financial reasons, debts, payment arrears, etc. Finally, inadequate access to basic social rights occurs when people do not attain essential minimum standards: lack of adequate health care, insufficient educational achievements, and no proper living environment.

Seen from this perspective, social exclusion theoretically occurs if someone is deprived simultaneously on several of these dimensions. In principle, we consider social exclusion and social inclusion as two sides of the same coin. While social inclusion may have stronger connotations of agency-as in governments or the European Union trying to combat social exclusion through policy measures, or organisations claiming to stimulate the careers of ethnic minorities, women or disabled people-there is no logical reason why intervening actors should not be part of the theoretical framework of social exclusion. Jehoel-Gijsbers and Vrooman (2007) state that in analysing the roots of social exclusion one should theoretically include the agents that bring about or solve the phenomenon. This may include various levels: individuals who exclude themselves or solve their own problems (e.g., deciding not to apply for a job, or fervent job-seeking behaviour); businesses and welfare organisations which exclude or include their clients (e.g., by denying someone a bank account because of the postcode in which they live, or by helping women to realise their rights); and communities and (supra)national governments, through the way they treat insiders and outsiders, or attribute legal rights and duties. From this point of view, the concept of social inclusion has little added value, and may even be considered as a case of linguistic amelioration (that is, the opposite of a pejorative expression).

On the other hand, in our theoretical framework we consider it important to distinguish social exclusion from poverty. Sen (1992, p. 109) famously noted that poverty is about "the failure of basic capabilities to reach certain minimally acceptable standards". Poverty is therefore about impossibilities: it makes it difficult to realise the things people generally aspire to at a minimal level. Social exclusion, on the other hand, relates to a lack of "functionings", or actual realisations, in terms of social participation, normative integration, material deprivation and social rights (Sen, 1993, 2000; Jehoel-Gijsbers, Smits, Boelhouwer, \& Bierings, 2009, pp. 17-18, 23-24). Money, wealth and other economic resources can be regarded as capabilities that matter in attaining these functionings; and poverty is therefore a risk factor with regard to social exclusion. However, other risk factors (health, level of education, job status) may be involved as well; and theoretically a person may be socially excluded without being poor-and vice versa-as shown in the rather weak correlations often found in empirical studies (e.g., Devicienti \& Poggi, 2011; Saraceno, 2001; Whelan, Layte, \& Maître, 2004). Poverty theoretically also differs from material deprivation, one of the dimensions of social exclusion. A low income generally makes it difficult to attain the minimum necessities of one's community, while material deprivation refers to an actual lack of consumption. Obviously, persons of small means are likely to be materially deprived, but this is not necessarily the case; for instance, they may be receiving gifts from relatives or partly live off of the land. Finally, material deprivation is only one of the four dimensions of social exclusion. This implies that materially deprived people need not score high on social exclusion: they may partly compensate for their material lack if their social participation is high, if they show high normative integration, or if they have extensive social rights guaranteed by their community or state (e.g., free health care).

While there is an extensive literature on childhood deprivation and its possible impacts (cf., Bradshaw, Hoelscher, \& Richardson, 2007; Bradshaw, Martorano, Natali, \& Neubourg, 2013; Forrest \& Riley, 2004; Gregg \& Machin, 1999; Hobcraft, Hango, \& Sigle-Rushton, 2004; UNICEF, 2007), the meaning of social exclusion among children is often taken for granted. This is apparent, for example, in various studies which relate the concept to the socio-psychological basis of peer group rejection among teenagers, or to the neurobiological roots and impact of isolation and ostracism among children (Crowley, Wu, Molfese, \& Mayes, 2010; Gunther Moor et al., 2012; Hawes et al., 2012; Sebastian, Viding, Williams, \& Blakemore, 2010). In this type of research the theoretical meaning of social exclusion among children tends to be left unclear, and its essentially sociological nature is often discarded. In other instances, social exclusion among children is mostly linked to material conditions and little information is provided about trajectories during the life course (see, however, Abello, Gong, Daly, \& McNamara, 2012; 
Bäckman \& Nilsson, 2011; Peruzzi, 2014).

In the current project we presume that, theoretically, the social exclusion concept is the same for children, but that it will be necessary to develop specific indicators which allow for their different needs and social contexts. For children "social participation" does not consist of the degree of social engagement and professional or social networks, but rather of things like hosting birthday parties or playing with friends. Normative integration for adults is likely to refer to work ethic and honesty, while for young people it might be more evident to look at things such as truancy, being suspended from school and delinquent juvenile behaviour (petty theft, vandalism). While payment arrears on rent or mortgage may indicate that adults are materially deprived, in the case of children it would probably make more sense to assess whether they are unable to take part in school trips because of lack of money. And finally, while among adults the dimension "access to basic rights" concerns aspects such as housing, health care and social security, for children it would be more logical to study whether they grow up in a safe neighbourhood, are able to follow the education they want, etc.

The operationalisation of social exclusion for the specific case of children was one of the main elements of the project discussed here, known by its Dutch acronym ASOUK (Poverty and social exclusion among children). We built upon previous work conducted the Netherlands Institute for Social Research /SCP over the past decade on measuring social exclusion in adults using questionnaires. In its original form the instrument consisted of 72 variables, divided into subscales for the four theoretical sub-dimensions (Jehoel-Gijsbers, 2004; Jehoel-Gijsbers \& Vrooman, 2007). Later versions contained fewer items (e.g., Jehoel-Gijsbers \& Vrooman, 2008a, 2008b), and Vrooman and Hoff (2013) recently developed an improved and shortened index consisting of 15 items, with three to four indicators for each of the theoretical elements of social exclusion (see also Hoff \& Vrooman, 2011). According to this instrument, just under $5 \%$ of the adult Dutch population were faced with a serious degree of social exclusion. The adult social exclusion index was also validated in Turkey (Bayram, Bilgel, \& Bilgel, 2012) and in a large-scale Dutch health survey (Van Bergen, Hoff, Van Ameijden, \& Van Hemert, 2014). As a follow-up to a joint methodological project by the Netherlands Institute for Social Research|SCP and Statistics Netherlands (JehoelGijsbers et al., 2009), Couman and Schmeets (2014) also performed an analysis of the index. This was based on the 2010 Dutch EU-SILC module and resulted in a similar prevalence. The project discussed here is the first to study social exclusion among children from the perspective of these four theoretical dimensions simultaneously, both in the Netherlands and elsewhere. This applies to both the cross-sectional and the longitudinal parts of the current paper.

\section{Data and Methodology}

In order to answer the first empirical research questions-index construction, prevalence and driving factors of social exclusion - the project started out with a random sampling frame consisting of 40,000 children living in private households, within the age range of 517 years in 2008. This was developed by Statistics Netherlands, who also linked each child to its parent(s) or caretaker(s) using the Municipal Personal Records Database. Subsequently parental income data (over 2006) were linked from the Social Assistance Database and the Integral Wages and Benefits Database. From this enriched database Statistics Netherlands then drew a stratified sample of 4,151 children, with an overrepresentation of poor children in households in receipt of social assistance benefit, other poor children, and children from non-Western ethnic minorities. This sample was subsequently provided to Intomart|Gfk, which performed the fieldwork using computer-aided personal interviews. Separate questionnaires for children and their parents were developed by the Netherlands Institute for Social Research|SCP. This included elaborate testing through cognitive interviews. The net response to the final questionnaire was $54 \%(2,202$ completed parent/child interviews). Statistics Netherlands calculated weights based on the original sampling frame, correcting for oversampling and selective response. After weighting, the final sample (ASOUK'08) may be considered representative for the entire population of Dutch children aged 5-18 years; it combines the data from the survey and several administrative databases. Jehoel-Gijsbers (2009, pp. 84-93) and Roest, Lokhorst, \& Vrooman (2010) provide more detailed accounts of the data-gathering procedure. The data were also used to assess the ex ante effects of proposed changes in Dutch child income schemes (Hoff \& Soede, 2013). The unit of analysis is at individual child level. The survey has been placed in the public domain through the Netherlands Data Archiving and Networked Services (DANS).

In order to analyse scarring effects the ASOUK project used a further combination of administrative data and a dedicated survey (see Guiaux, Roest, \& ledema, 2011 for a more elaborate discussion). The large-scale Income Panel Survey (IPO), developed by Statistics Netherlands and based on data from the Dutch tax administration and other government organisations, was the starting point for the analysis of scarring effects. This administrative panel has been running since the mid-1980s, and currently covers about 94,000 households containing 272,000 persons. IPO makes it possible to assess income sources and levels, household composition, age, etc., and changes therein over a period of more than a quarter of a century. The advantage of the panel is that it is large, accurate (no selfreports) and non-selective (no panel attrition because people no longer wish to participate). However, the da- 
ta are obviously limited to what is recorded in the administrative sources, and therefore do not contain information on a number of background variables (such as education) or on social exclusion. Statistics Netherlands provided a sample of 2,068 people who were aged 8-12 years in 1985 , in order to gather additional information. The age limits were set in this way because we wanted to analyse a homogeneous primary school group, with sufficient but comparable potential exposure to scarring. Of this group-at the time of the survey aged 32-36 years-996 persons participated in a computer-aided personal interview conducted by Intomart|Gfk in 2009 , a response rate of $48 \%$. About a third of the original sample lived in a poor household as a child; the remainder were non-poor. Statistics Netherlands corrected for the oversampling of poor children by providing weights based on the sampling frame. After weighting, the sample may be considered representative for all children aged 8-12 years living in independent households in the Netherlands in 1985. As adults they provided retrospective information about their situation during three life stages: when they were between 8 and 12 years old, between 13 and 18 years old, and in adult life. For all three phases the degree of social exclusion was established and they were asked about the kind of upbringing they had experienced, the education followed, their health status, employment and unemployment, etc. For each survey respondent Statistics Netherlands linked the administrative data that were available from the Income Panel Survey. The unit of analysis is at the level of individual adults from two childhood poverty strata. The survey data were also deposited with DANS.

In order to construct social exclusion scales we used nonlinear principal components analysis. This technique reduces variables to a limited number of uncorrelated dimensions, but unlike classic PCA it also entails a process of optimal quantification. Here, categories are assigned numerical values in such a way as to maximise the accounted-for variance in the transformed variables (see Gifi, 1990; Linting, Meulman, Groenen, \& Van der Kooij, 2007; Michailidis \& De Leeuw, 1998). Compared to classic PCA, the nonlinear variant has several advantages, mostly because it is able to handle nominal, ordinal and numerical data and does not assume a linear relationship between variables. In the SPSS software package we used, the technique is known as CatPCA. For structural equation modelling the MPlus package was used.

\section{Index Construction}

As mentioned earlier, the operationalisation of social exclusion has been adapted in order to reflect the specific contexts that children experience. This not only implies that we posed questions reflecting those aspects of social participation, normative integration, material deprivation and access to social rights that were meaningful to children; the questionnaire also had to take account of the fact that children aged 5 years live in different settings from 12 or 16 year-olds. For that reason, some questions were varied according to age, and others were only posed to older children. Appendix A contains an overview of the items we used in the current analysis; Roest et al. (2010) provide a more detailed account. In constructing our indices, we started out by performing nonlinear principal components analyses for three age categories: all children aged $5-17$ years, the group over 8 years of age, and the $12+$ group. The fact that various questions could not be posed to the very young children (5-7 years) soon turned out to be a major limitation. For instance, they were not questioned about their Internet contacts, an important element of participation among older children; and they only had one item for normative integration. This made it impossible to construct reliable (sub-)indices for this age group.

The choice between the two remaining age categories was less clear-cut. If we were to confine ourselves to young people aged between 12 and 18 years, we would maximise the number of items. This implies in particular that a more reliable scale is available for "normative integration". The category aged 12 years and over were presented with fourteen items for this sub-dimension, of which nine items remained, with a high internal consistency and clearly relating to defective behaviour (e.g., theft, vandalism, burglary, beating up others). The younger age group only had to answer four items about bullying and problems at school, with only two items remaining. On the other hand, this would result in an instrument with smaller coverageonly relating to children of secondary school age-and the number of cases would drop by 800 if we were to discard children in the 8-11 age bracket, thus decreasing the power of our subsequent analyses. For these reasons we ultimately decided to base our index on the $8+$ age group. Several items were excluded, as these applied to a rather small proportion ( $15 \%$ or less) of either the 8-11 year-olds or 12+ category, and the difference between the two age groups was statistically significant. This was the case for items on karting and going to a music festival or discotheque, for example.

Table 1 shows the results of CatPCA-analyses for the children and adolescents aged 8-17 years. The final scale for social participation contains twelve items, varying from taking part in sports and various recreational activities to contacts with friends. The normative integration scale, however, only consists of two items (bullying and being suspended) and has low reliability. The dimension "access to social rights" contains seven items, but these mostly relate to play areas and places to meet other children. It is fairly reliable, but somewhat limited in its coverage: the questions about access to education (e.g., being denied entry) or safety in 
the wider neighbourhood could not be included. Finally, the index for material deprivation consists of four items only; however, it is fairly reliable and seems wide enough in terms of validity, as it refers to both basic provisions (a separate bedroom, a suitable place for doing homework) and items of a more luxurious nature (having a mobile phone, an iPod). It should be noted that the general quality of life of Dutch children is quite high. They rank first on UNICEF's overall index of child well-being in 21 developed countries, especially in terms of subjective well-being, health and safety; for instance, the Netherlands has the second-highest percentage of young people who report that they eat breakfast on every schoolday (UNICEF, 2007). This im- plies that "harder" indicators of material deprivation, such as malnutrition, tend to have limited variance in the Netherlands (at least among the non-hospitalised children studied here), and these were not included.

In order to construct a general social exclusion scale, the object scores of the four sub-dimensions were added together and standardised so as to obtain a summary measure with an average of zero and unity standard deviation. The internal consistency of the scale is acceptable: 0.65 is slightly below the usual norm of 0.70 , but this reflects the multidimensional nature of the social exclusion concept. Figure 1 shows the distribution thus obtained for children on the general social exclusion index.

Table 1. Scales for four sub-dimensions of social exclusion (CatPCA, children aged 8-17 years; $n=1782)^{a, b}$.

Component loadings

\section{Lack of social participation ( $\alpha=.75)$}

$\begin{array}{ll}\text { Takes part in a sport (no) } & .41\end{array}$

$\begin{array}{ll}\text { How often to the zoo ((almost) never) } & .41\end{array}$

How often to an amusement park ((almost) never) $\quad .44$

$\begin{array}{lr}\text { How often to a museum ((almost) never) } & .40\end{array}$

How often to the theatre ((almost) never) $\quad .47$

How often to the cinema ((almost) never) $\quad .49$

How often to a bowling game ((almost) never) $\quad .49$

$\begin{array}{ll}\text { How often to an ice skating rink ((almost) never) } & .47\end{array}$

$\begin{array}{lr}\text { Invite friends to home (never) } & .68\end{array}$

Playing with friends, visiting friends (never) $\quad .65$

$\begin{array}{ll}\text { Invited friends for last birthday party (no) } & .57\end{array}$

Going to friends' birthday parties (never) $\quad .65$

Lack of normative integration ( $\alpha=.20)$

$\begin{array}{ll}\text { Bullying others (often) } & .65\end{array}$

Suspended from school, sent home by way of punishment (often)

Limited access to social rights $(\alpha=.84)$

Sufficient play areas/meeting places in the neighbourhood (no) $\quad .71$

Play areas/meeting places sufficiently safe (no) $\quad .70$

Play areas/meeting places often damaged (yes) $\quad .74$

$\begin{array}{ll}\text { Play areas/meeting places well-equipped (no) } & .77\end{array}$

$\begin{array}{ll}\text { Safe route to play areas/meeting places (no) } & .77\end{array}$

Play areas/meeting places kept clean (no) $\quad .75$

Enough going on in the neighbourhood for children/youngsters (no) $\quad .50$

Material deprivation $(\alpha=.43)$

$\begin{array}{ll}\text { Has a separate bedroom (no) } & .57\end{array}$

$\begin{array}{ll}\text { Has a suitable place to do homework (no) } & .68\end{array}$

Has a mobile phone of his/her own (no) $\quad .62$

$\begin{array}{ll}\text { Has an iPod (no) } & .54\end{array}$

Notes: ${ }^{a}$ In parentheses: response indicative of social exclusion; ${ }^{b}$ The complete list of items is presented in appendix A. Source: ASOUK'08 data set. 


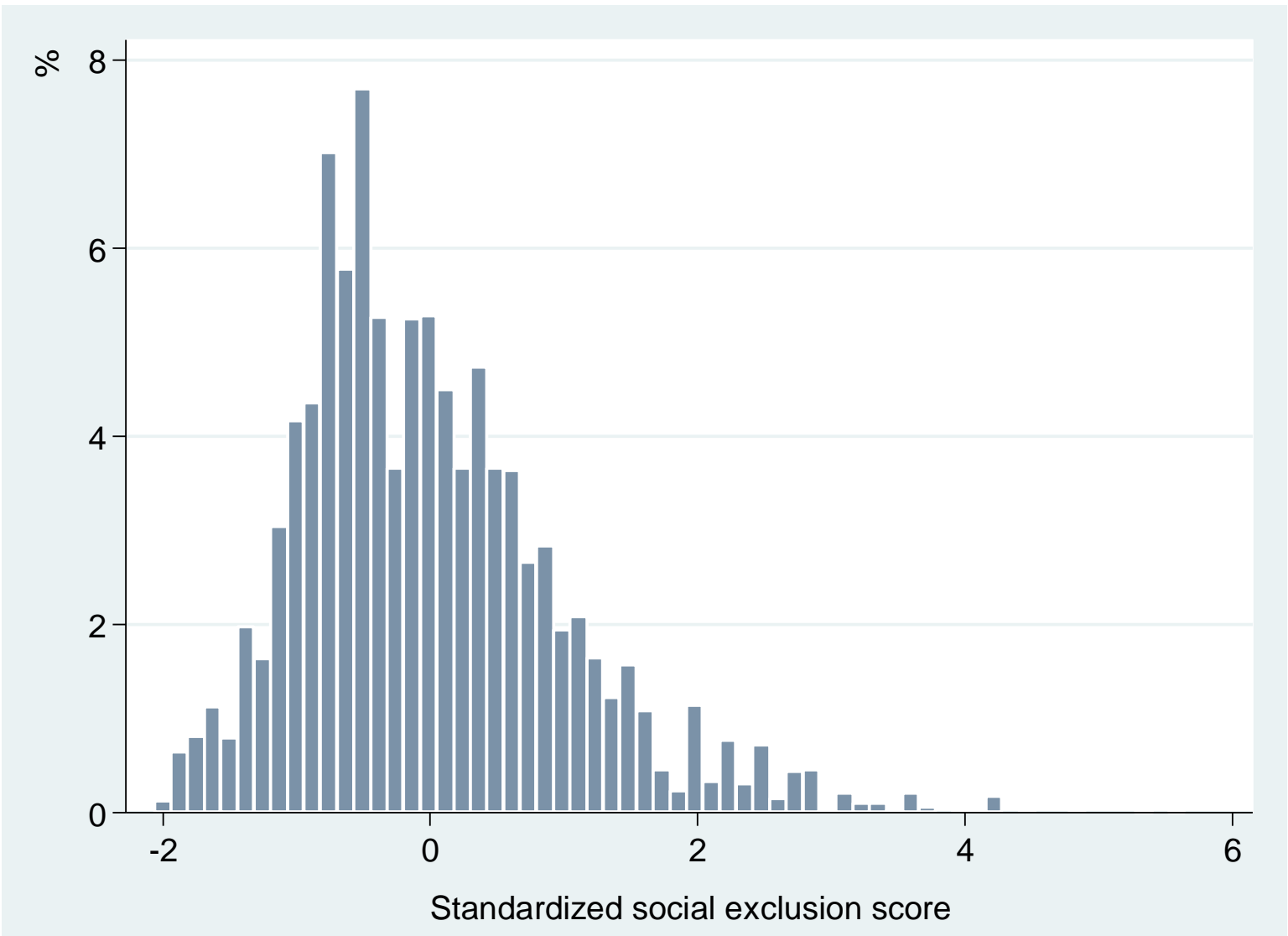

Figure 1. Distribution on the general social exclusion scale for Dutch children aged 8-17 years (CatPCA object scores, weighted sample). Source: ASOUK'08 dataset.

Table 2. Relationships between sub-dimensions and the general social exclusion index for Dutch children (Pearson correlations, weighted sample).

\begin{tabular}{|c|c|c|c|c|c|}
\hline Scale & $\begin{array}{l}\text { Lack of social } \\
\text { participation }\end{array}$ & $\begin{array}{l}\text { Lack of } \\
\text { normative } \\
\text { integration }\end{array}$ & $\begin{array}{l}\text { Limited } \\
\text { access to } \\
\text { social rights }\end{array}$ & $\begin{array}{l}\text { Material } \\
\text { deprivation }\end{array}$ & $\begin{array}{l}\text { General } \\
\text { social } \\
\text { exclusion } \\
\text { scale }\end{array}$ \\
\hline Lack of social participation & 1.00 & & & & \\
\hline Lack of normative integration & $0.13^{* *}$ & 1.00 & & & \\
\hline Access to social rights & $0.05^{*}$ & 0.03 & 1.00 & & \\
\hline Material deprivation & $0.11^{* *}$ & -0.00 & $-0.11 * *$ & 1.00 & \\
\hline General social exclusion scale & $0.60 * *$ & $0.54 * *$ & $0.51 * *$ & $0.44^{* *}$ & 1.00 \\
\hline
\end{tabular}

Notes: * Significant at $\mathrm{p}<0.05 ; * *$ Significant at $\mathrm{p}<0.01$. Source: ASOUK'08 data set.

Table 2 presents the correlations between the subscales and the general index. It turns out that the overall child social exclusion scale is fairly strongly related to all four sub-dimensions $(0.44<r<0.60)$. This supports our assumption that the subscales each cover a different aspect of social exclusion. Furthermore, the subscales cannot be reduced to each other: the correlations are generally quite low $(0.00<r<0.13)$. The weak relationships between the subscales and their strong correlation with the general index corroborates our theoretical notion of social exclusion as a multidimensional concept.

\section{Prevalence and Driving Factors of Social Exclusion}

Since social exclusion is essentially a relative phenomenon, and our general index is a continuous one, there is no natural threshold which separates the excluded from the non-excluded. In a recent study among Dutch adults we defined threshold values based on gaps that appeared when the distribution on the social exclusion index was plotted against that of subjective feelings of social exclusion (Vrooman \& Hoff, 2013). This method cannot be used here, because in the present survey we did not ask about children's subjective feelings of social 
exclusion, the content of the social exclusion items differs, and of course the target group of children is quite different.

In order to assess the prevalence of social exclusion we therefore assumed that children with a score equal to or below the mean of the general index may be considered to be not or barely socially excluded. For children with scores above the mean value we defined further cut-off points at one, two and three or more standard deviations above the mean. Table 3 shows the results of this classification into prevalence categories, both in terms of the (weighted) shares of all children, and their absolute numbers.

Table 3. Prevalence of social exclusion among Dutch children, 2008 (in percentages and absolute numbers; general index, weighted sample).

\begin{tabular}{lcc}
\hline Degree of social exclusion & $\%$ & $\mathbf{n ~ ( x ~}$ \\
& & $\mathbf{1 0 0 0})$ \\
\hline $\begin{array}{l}\text { Not or barely excluded (equal } \\
\text { to or below mean=0.00) }\end{array}$ & 56.6 & 968.9 \\
$\begin{array}{l}\text { Slightly excluded (0.01-1.00) } \\
\text { Somewhat excluded }\end{array}$ & 29.2 & 499.3 \\
$\begin{array}{l}\text { (1.01-2.00) } \\
\text { Excluded (2.01-3.00) }\end{array}$ & 9.8 & 167.5 \\
$\begin{array}{l}\text { Very excluded (3.01 and } \\
\text { higher) }\end{array}$ & 3.5 & 59.7 \\
\hline
\end{tabular}

Source: ASOUK'08 data set.

Based on our chosen threshold values, $43 \%$ of Dutch children may be considered socially excluded to some degree. In most cases this concerns lighter forms of exclusion, but $4.5 \%$ can be regarded as excluded or very excluded, corresponding to about 77,000 children aged 8-17 years. In an alternative coding scheme, we divided the range between the theoretical minimum and maximum scores on the index in five equal categories. This led to a lower estimate, with $1.9 \%$ of the child population being excluded or very excluded. The difference is due to the fact that the highest empirical scores are considerably below the theoretical maximum: none of the children in our sample attained maximum social exclusion on all 25 items.

With regard to the four subscales, we followed the same procedure as previously (Table 4). Just over $4 \%$ are excluded or very excluded in terms of social participation (sports, excursions and contacts with friends); but more than $40 \%$ show weaker forms of exclusion in this respect. About $3 \%$ of the children are excluded or very excluded as regards lack of normative integration, as indicated by bullying and experiencing disciplinary measures at school. Three-quarters of all children exhibit hardly any defective behaviour of this kind. Exclusion in terms of access to social rights is fairly common, with over $6 \%$ of children being excluded or very ex- cluded. However, it should be borne in mind that this subscale relates to the presence of safe, well-equipped and clean play and meeting areas for children. Although this is quite a relevant aspect of their living environment, it does not necessarily imply large deficits in terms of health care or access to education. Finally, about $4 \%$ of all Dutch children in the 8-17 age range are excluded or very excluded in terms of material deprivation: they tend to lack a bedroom of their own, a suitable place to do homework, a mobile phone or an iPod. On the other hand, two-thirds are not or barely excluded in this respect.

\subsection{Links between Social Exclusion and Risk Factors}

Earlier research into social exclusion among adults has identified several risk factors, such as poor health, low subjective well-being, being of non-Western ethnic origin and single parenthood (Jehoel-Gijsbers \& Vrooman, 2007, 2008a; Vrooman \& Hoff, 2013). The bivariate relationships in Table 5 indicate the risk factors for children, and this is largely in line with the results found for adults earlier. Children whose parents are without work or on benefit, or who have a lower education level or are in poverty, are more likely to be socially excluded. Poverty was measured on the basis of SCP's "modest but adequate" criterion - the number of people with a standardised disposable income below a national budget standard based on a combination of expert opinions and consensual methods, as recommended by Bradshaw and Mayhew (2010); see Soede and Vrooman (2008); Vrooman (2009, pp. 344-426); Hoff et al. (2010) and SCP/CBS (2014). Boys, children of non-Western ethnic origin and children living in large families are also at higher risk of social exclusion. On closer inspection, the gender difference turns out to be due to less social participation and less normative integration among boys. Regional effects are limited (not shown in table): we only found a significant difference between the northern and western regions of the country (NUTS-1 level; largest cities excluded). Social exclusion is somewhat higher in the provinces of Groningen, Friesland and Drenthe, while children living in the western provinces (outside Amsterdam, Rotterdam, The Hague and Utrecht) experience less social exclusion. However, the data do not contain information at the level of individual municipalities or neighbourhoods.

After correcting for the impact of other variables, the direct effects of some factors are no longer statistically significant, while the effects of several others become weaker. The most dominant traits that emerge from the multivariate analysis are parental level of education and benefit recipiency of at least one of the parents. The number of siblings and the child's gender also remain influential. Taken together, these characteristics explain $13 \%$ of the variance in the social exclusion scale. 
Table 4. Prevalence of four aspects of social exclusion among Dutch children, 2008 (in percentages; subscales, weighted sample).

\begin{tabular}{lllll}
\hline & $\begin{array}{l}\text { Lack of social } \\
\text { participation }\end{array}$ & $\begin{array}{l}\text { Lack of } \\
\text { normative } \\
\text { integration }\end{array}$ & $\begin{array}{l}\text { Limited access } \\
\text { to social rights }\end{array}$ & $\begin{array}{l}\text { Material } \\
\text { deprivation }\end{array}$ \\
\hline $\begin{array}{l}\text { Not or barely excluded (equal to or } \\
\text { below mean=0.00) }\end{array}$ & 54.7 & 75.8 & 67.3 & 65.7 \\
Slightly excluded (0.01-1.00) & 30.2 & 20.2 & 23.9 & 26.3 \\
Somewhat excluded (1.01-2.00) & 10.9 & 0.9 & 2.6 & 3.9 \\
Excluded (2.01-3.00) & 3.3 & 0.9 & 2.6 & 2.8 \\
Very excluded (3.01 and higher) & 1.0 & 2.2 & 3.6 & 1.3 \\
\hline
\end{tabular}

Source: ASOUK'08 data set.

Table 5. Relationships between the general social exclusion scale and various risk factors among Dutch children, 2008 (standardised regression coefficients of dummy variables, weighted sample).

\begin{tabular}{|c|c|c|}
\hline & bivariate & multivariate \\
\hline \multicolumn{3}{|l|}{ Gender } \\
\hline - girl & Ref. & Ref. \\
\hline - boy & $.13^{* *}$ & $.14^{* *}$ \\
\hline \multicolumn{3}{|l|}{ Age } \\
\hline - 8-11 years & Ref. & Ref. \\
\hline - 12 years or older & -.05 & -.06 \\
\hline \multicolumn{3}{|l|}{ Ethnic origin } \\
\hline Dutch & Ref. & Ref. \\
\hline Foreign, non-Western country & $.16^{* *}$ & .07 \\
\hline Foreign, Western country & -.03 & -.03 \\
\hline \multicolumn{3}{|l|}{ Parent lives with spouse } \\
\hline- no & Ref. & Ref. \\
\hline - yes & $-.08 *$ & .02 \\
\hline \multicolumn{3}{|l|}{ Number of siblings } \\
\hline - none & Ref. & Ref. \\
\hline-1 & .01 & .03 \\
\hline-2 & .08 & .09 \\
\hline-3 & .07 & .07 \\
\hline-4 or more & $.16^{* *}$ & $.13^{* *}$ \\
\hline \multicolumn{3}{|c|}{ Highest level of education of parents } \\
\hline - lower secondary or less & Ref. & Ref. \\
\hline - higher secondary & $-.18 * *$ & $-.10 *$ \\
\hline - tertiary & $-.26 * *$ & $-.16^{* *}$ \\
\hline \multicolumn{3}{|c|}{ Main source of income at household level ${ }^{\mathrm{a}}$} \\
\hline - wages and salaries & Ref. & Ref. \\
\hline - business profits & -.04 & -.04 \\
\hline - social security benefit & $.19 * *$ & .06 \\
\hline - other & -.02 & -.02 \\
\hline \multicolumn{3}{|l|}{ At least one parent in work ${ }^{b}$} \\
\hline- no & Ref. & Ref. \\
\hline - yes & $-.17 * *$ & .03 \\
\hline \multicolumn{3}{|l|}{ At least one parent on benefit ${ }^{b}$} \\
\hline- no & Ref. & Ref. \\
\hline - yes & $.22 * *$ & $.13^{*}$ \\
\hline \multicolumn{3}{|l|}{ Child is part of poor household ${ }^{a}$} \\
\hline- no & Ref. & Ref. \\
\hline - yes & $.11^{* *}$ & .04 \\
\hline
\end{tabular}


Roest et al. (2010) performed a more elaborate multivariate analysis on the same dataset using structural equation modelling (although register data for 2008 were not available at the time). Their findings suggest two pathways towards social exclusion in childhood. The first route consists mainly of financial/economic characteristics: poverty and being out of work lead to material deprivation on the part of parents, which in turns leads to social exclusion of the children. As parents of non-Western origin and those who live alone are more likely to be without paid employment, they are also at greater risk of poverty and material deprivation, which translates into higher social exclusion among their offspring. In addition, there is a social/cognitive route: parents with a low level of education are more likely to experience social exclusion themselves (especially in terms of low social participation), and controlling for all other factors in the structural model, this is a direct determinant of social exclusion in their children. The two pathways identified by Roest et al. (2010) thus indicate rather intricate causal mechanisms. However, because the coefficients are statistically significant but rather low, and also become diluted the further back they are located in the causal chains, there is no single parameter that policymakers can use in seeking to combat social exclusion during childhood.

\section{Scarring Effects of Poverty and Social Exclusion?}

In line with our theoretical conceptualisation, we drew a distinction between poverty and social exclusion in the study of scarring effects in the ASOUK project. The administrative data allowed us to carry out a detailed analysis of the "reproduction of poverty" from childhood through to adult life. The same definition of poverty was used as in the prevalence study discussed earlier. This analysis showed that, of those people who were living in a poor family as a child in $1985,7 \%$ were still poor as adults in 2008. This may seem rather low, but their poverty risk is almost twice as high as for those who were not poor during childhood, only $4 \%$ of whom were poor in 2008. In addition, the adult poverty risk increases if childhood poverty occurred during an extended period of time: people who were poor as a child in both
1985 and 1989 had a $15 \%$ risk of being poor as an adult in 2008. Even so, in both cases the majority of people who grew up in poverty were not poor as adults. Poverty during childhood therefore does not automatically imply that those concerned are destined for poverty in later life, at least not in the Netherlands during the period studied in the ASOUK project (Guiaux et al., 2011).

For the three periods in the life of the respondents examined in the scarring effects study, the social exclusion scales diverge from those discussed in the previous section (see Table 6). These differences stem from the need to pose retrospective questions with regard to childhood experiences, and from limitations on the number of items that could be included in the questionnaire. Appendix B lists all scale items for the various ages of our respondents.

Poverty during childhood also increases the risk of social exclusion, both as a child and in later life. The main differences in social exclusion between poor and non-poor children relate to the areas of social participation and material deprivation. Children growing up in a poor family usually did not go on holiday every year, and lacked certain luxury (or even basic) goods. Also, joining a sports club or participating in other social activities was often out of the question in poor families. In some cases, these differences remained in adulthood. However, growing up poor did not affect the other two theoretical aspects of social exclusion: people who were poor in early childhood did not show deficits in terms of normative integration and access to social rights when they reached adolescence or in their adult lives. However, there is a small effect of long term childhood poverty (being poor in both 1985 and 1989) on access to social rights in 2008.

The routes linking poverty and social exclusion during childhood and in later life are presented in a more formalised way in Figure 2. This shows the outcomes of the structural equation model, as estimated in MPlus. It contains the main effects only: a host of other variables gathered in the survey (also mostly translated into scales) were not included because they were insignificant in statistical terms or could not be regarded as mediating factors.

Table 6. Social exclusion scales available in the scarring effects study.

\begin{tabular}{llll}
\hline & As child 8-12 years & As child 13-18 years & As adult \\
\hline Respondent & Lack of social participation & Lack of social participation & Lack of social participation \\
& Material deprivation & Material deprivation & Material deprivation \\
& Lack of normative integration & Lack of normative integration \\
& Limited access to social rights & Limited access to social rights \\
& & General social exclusion index
\end{tabular}

Parent Lack of social participation

Material deprivation

Source: Guiaux et al. (2011). 
The latter include the number of siblings and changes in household composition (e.g., parental divorce); family climate and parenting skills (consistent behaviour, mutual respect, aggression, cleanliness); parental involvement at school and their support in social activities (attending school plays and sports contests); parents' ability to help with homework for Dutch, English and mathematics; the reading climate (number of books in the household, reading at bedtime); language proficiency (speaking standard Dutch, a local dialect or a foreign language at home); the occurrence of physical or mental illness, disability and unemployment of the parents during the respondent's youth; being bullied at school; being a young parent, etc. The full questionnaire is available in Dutch at www.scp.nl (appendices to Guiaux et al., 2011). The final model as presented here includes those variables that:

a) were potential mediators between poverty/ social exclusion in childhood and adult life (as indicated by significant bivariate correlations with both phases); or

b) were correlated with childhood poverty and social exclusion but logically preceded it (e.g. the parent's ethnic origin or education level), implying that it might be a "deeper cause"; and c) remained significant in the multivariate structural equation model (see Guiaux et al. 2011 for a more detailed discussion, and Appendix $\mathrm{C}$ for an overview of the standardised total effects of all model variables).

Two main routes can be distinguished. First, poor children have less access to socioeconomic resources, leading to less participation in all kinds of social activities during their childhood and, as a result of this, to a lower education level. This in turn adversely affects their labour market prospects and income position as an adult. The second route operates via health: poor children more often have health problems, which increases the risk of being unhealthy as an adult. Because of their relatively poor health, they also attain a lower education level, and this again adversely influences their chances on the labour market.

As Figure 2 shows, educational attainment is a central factor in both routes from childhood to adulthood as regards poverty and social exclusion. The role of education actually starts a generation earlier: if the child's father has a low education level, it is more likely that his children will grow up in poverty and that their educational attainment will also be lower. More importantly, there is a strong direct effect of the father's education.

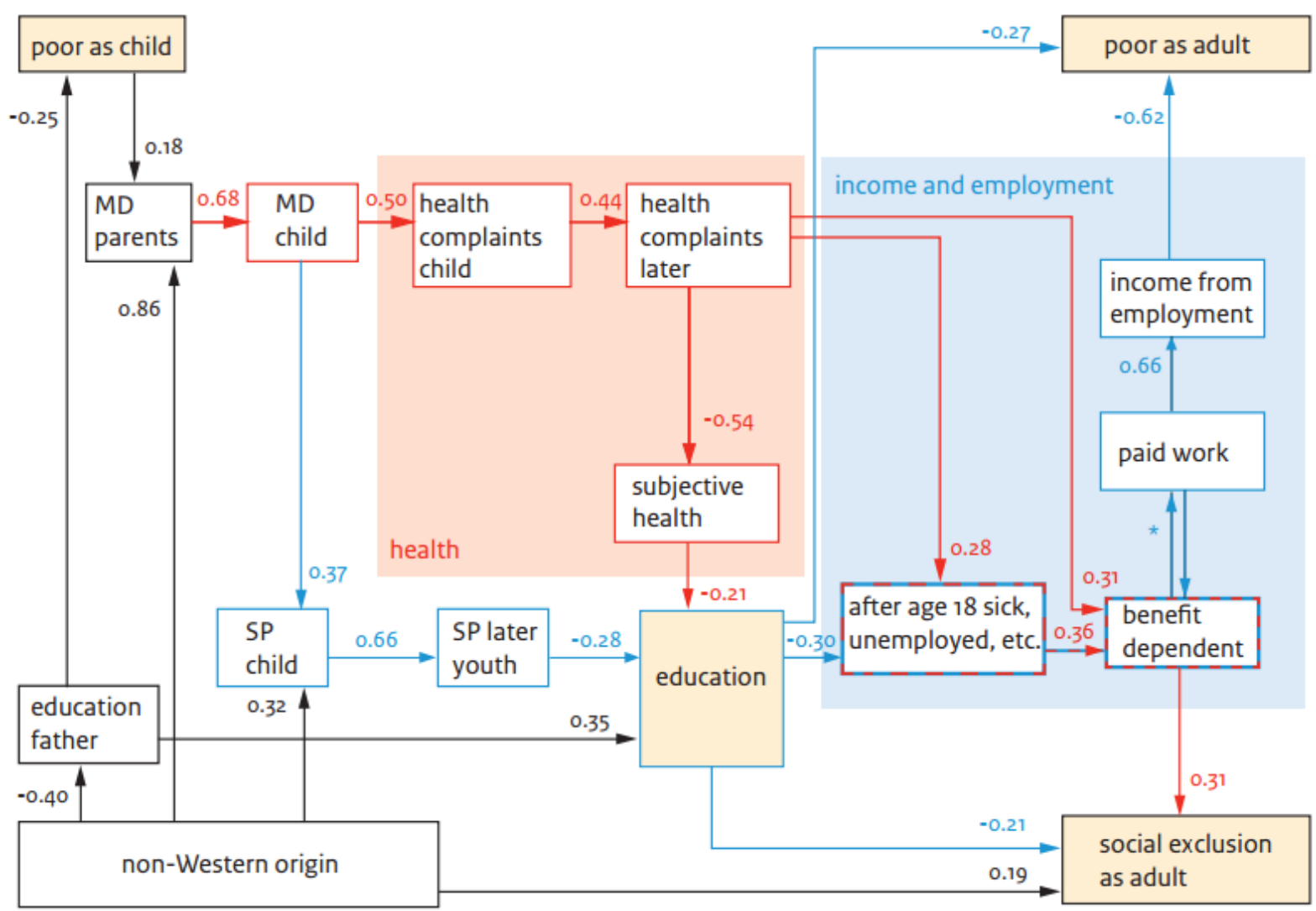

Figure 2. Routes from poverty and social exclusion in childhood to adult life (main standardised effects). Notes: MD = material deprivation; SP = social participation ; * The unstandardised effect was constrained to be equal in the model; after standardisation the parameter values are unequal: paid work $=-0.56$ (benefit dependent); benefit dependent $=$ -0.08 (paid work). Source: ASOUK'09 data set; Guiaux et al. (2011). 
Another important characteristic is the person's ethnic background. A non-Western origin increases both the risk of poverty in childhood and the likelihood of social exclusion in adult life. People of non-Western origin were more often poor as children, experiencing more material deficits and less social participation in their youth. Eventually, this translates into a higher degree of social exclusion.

Whereas education, work, health status, ethnic origin and social participation are crucial in determining poverty and social exclusion in adult life, other characteristics are found to be less important (Guiaux et al., 2011). For instance, there is no independent effect of the family climate: although there is more aggression and a less calm and regular atmosphere in poor families, this does not increase the risk that poor children will develop into poor and socially excluded adults.

Overall, this study shows that poverty in childhood translates to only a limited extent into poverty and social exclusion in later life. However, the $7 \%$ of poor children who are still poor in adulthood seem to be indicative of scarring, although the model suggests this is an indirect effect and one that to a large extent depends on preceding factors (father's education, ethnic origin). Policy interventions to combat scarring effects should probably focus on improving the educational attainment of poor children, their health and their social participation. Children with low-educated fathers, with parents of non-Western origin and parents without work need extra attention in this respect.

\section{Conclusions}

This article provides an overview of the outcomes of a large-scale research project conducted in the Netherlands on social exclusion and poverty among children. The first research question we addressed in this study was how to conceptualise social exclusion in the case of children. Here, we posited that social exclusion is theoretically related to the same four dimensions as for adults: limited social participation, a lack of normative integration, inadequate access to basic social rights, and material deprivation. However, as children differ from adults in their experiences, the meanings of these dimensions are likely to be different as well. The translation of the theoretical dimensions into a measurement instrument appropriate for children was one of the key aims of the study conducted by Roest et al. (2010). This resulted in indicators relating to aspects such as playing with friends (social participation), being suspended from school (normative integration), growing up in a safe neighbourhood (access to basic social rights) and taking part in school trips (material deprivation). For the current study we used these and similar indicators to construct a new index for social exclusion.

A second research question was whether it is actually possible to construct an instrument to measure so- cial exclusion among children, which covers both the general construct and the sub-dimensions using new survey data. In order to answer this question, we first performed nonlinear principal components analyses for each of the sub-dimensions. This resulted in a scale for "limited social participation" consisting of twelve items focusing on contacts with friends and recreational activities. For the sub-dimension "lack of normative integration" the analysis produced a two-item scale, relating to bullying others and suspension from school. "Limited access to social rights" was covered by seven items, relating to the presence and safety of playgrounds and meeting places for children and adolescents. Finally, the scale for material deprivation, the fourth dimension of social exclusion, consisted of some items referring to basic provisions, such as having a separate bedroom and luxury goods such as a mobile phone. Together, these 25 items made up a general scale with acceptable internal consistency. As would be expected with a multidimensional concept, we found rather weak relationships between the subscales, and fairly strong correlations with the general index.

The third research question was concerned with the prevalence and driving factors of social exclusion among children in the Netherlands. Based on the 25item scale produced and our chosen cut-off points, $43 \%$ of Dutch children were found to be socially excluded to some extent. While for most of them the degree of social exclusion is rather low, $4.5 \%$ may be considered to be excluded or very excluded. This corresponds to about 77,000 children aged $8-17$ years in the Netherlands. One of the main driving factors for social exclusion is the parental level of education: children whose parents attained no more than lower secondary school level are more likely to be socially excluded than those with better educated parents. Another factor which affects the likelihood of being excluded is whether the child lives in a family where one or both parents are receiving social security benefits.

The final research question concerned the "scarring effects" of poverty and social exclusion. The longitudinal ASOUK study covered a period of 23 years, and combined register data on income and household characteristics with a new survey, conducted among adults who were either poor on non-poor as a child. As regards poverty, scarring turned out to be limited (a large majority of poor children were non-poor as adults) but not entirely absent (poor children were at considerably greater risk of being poor as adults). However, structural equation modelling indicates that child poverty has only limited effects on social exclusion in adolescence (and then only in terms of material deprivation and lower social participation); and this, in turn, has rather modest and indirect effects on poverty and social exclusion in adult life. Scarring due to childhood poverty and social exclusion occurs, then, but its effects are mediated by children's educational 
achievements; and here we also found a strong direct effect of the father's level of education.

\section{Acknowledgements}

The ASOUK project was funded in part by the Dutch Ministry of Social Affairs and Employment and the former Ministry of Youth and Family.

\section{Conflict of Interests}

The authors declare no conflict of interests.

\section{References}

Abello, A., Gong, C. H., Daly, A., \& McNamara, J. (2012). Spatial dimensions of child social exclusion risk in Australia: Widening the scope. Child Indicators Research, 5(4), 685-703.

Bäckman, O., \& Nilsson, A. (2011). Pathways to social exclusion-A life course study. European Sociological Review, 27, 107-123.

Bayram, N., Bilgel, F., \& Bilgel, N. G. (2012). Social exclusion and quality of life: An empirical study from Turkey. Social Indicators Research, 105(1), 109-120.

Bradshaw, J., Hoelscher, P., \& Richardson, D. (2007). An index of child well-being in the European Union. Social Indicators Research, 80(1), 133-177

Bradshaw, J., \& Mayhew, E. (2010). The measurement of extreme poverty in the European Union. Brussels: European Union.

Bradshaw, J., Martorano, B., Natali, L., \& Neubourg, C. de (2013). Children's subjective well-being in rich countries. Child Indicators Research, 6(4), 619-635.

Coumans, M., \& Schmeets, H. (2014). The socially excluded in the Netherlands: The development of an overall index. Social Indicators Research, doi: 10.1007/s11205-014-0707-6

Crowley, M. J., Wu, J., Molfese, P. J., \& Mayes, L. C. (2010). Social exclusion in middle childhood: Rejection events, slow-wave neural activity, and ostracism distress. Social Neuroscience, 5(5), 483-495.

Devicienti, F., \& Poggi, A. (2011). Poverty and social exclusion: Two sides of the same coin or dynamically interrelated processes? Applied Economics, 43(25), 3549-3571.

Durkheim, E. (1897). Le suicide; étude de sociologie. Paris: Félix Alcan.

European Commission. (2011). Europe 2020 targets (as set by member states in their national reform programmes in April 2011). Brussels: European Commission. Retrieved from http://ec.europa.eu/ europe2020/pdf/targets_en.pdf

Elias, N., \& Scotson, J. L. (1965). The established and the outsiders: A sociological enquiry into community problems. London: Frank Cass.

Eurostat. (2014). People at risk of poverty or social ex- clusion. Luxembourg: Eurostat. Retrieved from http://ec.europa.eu/eurostat/statistics-explained/in dex.php/People_at_risk_of_poverty_or_social_exclu sion

Fahey, T. (2010). Poverty and the two concepts of relative deprivation. Dublin: University College.

Forrest, C. B., \& Riley, A. W. (2004). Childhood origins of adult health: A basis for a life course health policy. Health Affairs, 23, 155-164.

Gifi, A. (1990) Nonlinear multivariate analysis. Wiley: Chichester.

Gregg, P., \& Machin, S. (1999). Childhood disadvantage and success or failure in the labour market. In D. Blanchflower \& R. Freeman (Eds.) Youth employment and joblessness in advanced countries. Cambridge: National Bureau of Economic Research.

Guiaux, M., Roest, A., \& ledema, J. (2011). Voorbestemd tot achterstand? Armoede en sociale uitsluiting in de kindertijd en 25 jaar later [Destined for disadvantage? Poverty and social exclusion during childhood and 25 years later]. The Hague: Sociaal en Cultureel Planbureau.

Gunther Moor B., Guroglu, B., op de Macks, Z. A., Rombouts, S. A. R. B., van der Molen, M. W., \& Crone, E. A. (2012). Social exclusion and punishment of excluders: Neural correlates and developmental trajectories. Neurolmage, 59(1), 708-717.

Hawes, D. J., Zadro, L., Fink, E., Richardson, R., O'Moore, K., Griffiths, B., Dadds, M. R., \& Williams, K. D. (2012). The effects of peer ostracism on children's cognitive processes. European Journal of Developmental Psychology, 9(5) 599-613.

Hills, J., LeGrand, J., \& Piachaud, D. (Eds.). (2002). Understanding social exclusion. Oxford: Oxford University Press.

Hobcraft, J., Hango, D., \& Sigle-Rushton, W. (2004). The childhood origins of adult socio-economic disadvantage: Do cohort and gender matter? London: London School of Economics, Centre for Analysis of Social Exclusion.

Hoff, S., \& Vrooman, C. (2011). Dimensies van sociale uitsluiting. Naar een verbeterd meetinstrument [Dimensions of social exclusion. Towards an improved measurement instrument]. The Hague: Sociaal en Cultureel Planbureau.

Hoff, S., Soede, A., Vrooman, C., van Gaalen, C., Luten, A., \& Lamers, S. (2010). The minimum agreed upon; Consensual budget standards for the Netherlands. The Hague: The Netherlands Institute for Social Research|SCP and National Institute for Family Finance Information (Nibud).

Hoff, S., \& Soede, A. (2013). Maatschappelijke effecten van het wetsvoorstel Hervorming kindregelingen voor gezinnen met kinderen [Social effects for families with children of the proposed bill on the revision of child schemes]. The Hague: Sociaal en Cultureel Planbureau. 
Jehoel-Gijsbers, G. (2004). Sociale uitsluiting in Nederland [Social Exclusion in the Netherlands]. The Hague: Sociaal en Cultureel Planbureau.

Jehoel-Gijsbers, G. (2009). Kunnen alle kinderen meedoen? [Do all children participate?]. The Hague: Sociaal en Cultureel Planbureau.

Jehoel-Gijsbers, G., \& Vrooman, C. (2007). Explaining social exclusion: A theoretical model tested in the Netherlands. The Hague: The Netherlands Institute for Social Research|SCP.

Jehoel-Gijsbers, G., \& Vrooman, C. (2008a). Sociale uitsluiting in Nederland en Europa [Social exclusion in the Netherlands and in Europe]. In P. Schnabel, R. Bijl, \& J. de Hart (Eds.), Betrekkelijke betrokkenheid. Studies in sociale cohesie. Sociaal en Cultureel Rapport 2008 (pp. 237-258). The Hague: Sociaal en Cultureel Planbureau.

Jehoel-Gijsbers, G., \& Vrooman, C. (2008b). Social exclusion of the elderly; A comparative study of EU member states. Brussels: Centre for European Policy Studies.

Jehoel-Gijsbers, G., Smits, W., Boelhouwer, J., \& Bierings, H. (2009). Sociale uitsluiting: Een meetinstrument [Social exclusion: A measuring instrument]. The Hague: Sociaal en Cultureel Planbureau.

Levy, J. D. (2010). Welfare retrenchment. In F. G. Castles, S. Leibfried, J. Lewis, H. Obinger, \& C. Pierson (Eds.), The Oxford handbook of the welfare state (pp. 552-565). Oxford: Oxford University Press.

Lewis, O. (1969). Cultures of poverty. In P. Moynihan (Ed.), On understanding poverty: Perspectives from the social sciences. New York: Basic Books.

Linting, M., Meulman, J. J., Groenen, P. J. F., \& van der Kooij, A. J. (2007). Nonlinear principal components analysis. Psychological Methods, 12(3), 115-143.

Merton, R. K., \& Rossi, A. S. (1968). Contributions to the theory of reference group behavior. In R. K. Merton, Social theory and social structure (1968 enlarged ed.; pp. 279-334). New York: The Free Press.

Michailidis, G., \& de Leeuw, J. (1998). The Gifi system of descriptive multivariate analysis. Statistical Science, 13(4), 307-336.

$\varnothing$ yen, E. (1997). The contradictory concepts of social exclusion and social inclusion. In C. Gore \& J. B. Figueiredo (Eds.), Social exclusion and anti-poverty policy. Geneva: International Institute of Labour Studies.

Pantazis, C., Gordon, D., \& Levitas, R. (Eds.) (2006). Poverty and social exclusion in Britain; the millennium survey. Bristol: The Policy Press.

Paugam S. (1996). La constitution d'un paradigme. In S. Paugam (Ed.), L'exclusion, l'état des savoirs. Paris: La Découverte.

Peruzzi, A. (2014). From childhood deprivation to adult social exclusion. Evidence from the 1970 British Cohort Study. London: Centre for Longitudinal Studies.

Pierson, P. (1996). The new politics of the welfare state. World Politics, 48(2), 143-179.

Roest, A., Lokhorst, A. M., \& Vrooman, C. (2010). Sociale uitsluiting bij kinderen: omvang en achtergronden [The social exclusion of children; Prevalence and underlying causes]. The Hague: Sociaal en Cultureel Planbureau.

Room, G. (1997). Social quality in Europe; perspectives on social exclusion. In W. Beck, L. van der Maesen, \& A. Walker (Eds.), The social quality of Europe. The Hague: Kluwer Law International.

Runciman, W. G. (1966). Relative deprivation and social justice. London: Routledge and Kegan Paul.

Saraceno, C. (2001). Social exclusion; cultural roots and diversities of a popular concept. Columbia: Columbia University.

SCP/CBS. (2014). Armoedesignalement 2014 [Poverty Survey 2014]. The Hague: Sociaal en Cultureel Planbureau.

Sebastian C., Viding, E., Williams, K. D., \& Blakemore, S.-J. (2010). Social brain development and the affective consequences of ostracism in adolescence. Brain and Cognition, 72(1), 134-145.

Sen, A. (1992). Inequality re-examined. Cambridge (Mass.): Sage.

Sen, A. (1993). Capability and well-being. In M. Nussbaum \& A. Sen (Eds.), The quality of life (pp. 30-53). Oxford: Clarendon Press.

Sen, A. (2000). Social exclusion: Concept, explanation and scrutiny. Manila: Asian Development Bank.

Soede, A., \& Vrooman, C. (2008). Beyond the breadline: A poverty threshold based on a generalised budget approach. The Hague: The Netherlands Institute for Social Research|SCP.

UNICEF (2007). An overview of child well-being in rich countries; a comprehensive assessment of the lives and well-being of children and adolescents in the economically advanced nations. Florence: UNICEF Innocenti Research Centre.

Van Bergen, A.P.L., Hoff, S. J. M., van Ameijden, E. J. C., \& van Hemert, A. M. (2014). Measuring social exclusion in routine public health surveys: Construction of a multidimensional instrument. PLOS ONE, 9(5), e98680. doi: 10.1371/journal.pone.0098680

Vrooman, J. C., \& Hoff, S. J. M. (2013). The disadvantaged among the Dutch: A survey approach to the multidimensional measurement of social exclusion. Social Indicators Research, 39(3), 1261-1287.

Vrooman, J. C. (2009). Rules of relief; institutions of social security, and their impact. The Hague: The Netherlands Institute for Social Research |SCP.

Whelan, C. T., Layte, R., \& Maître, B. (2004). Understanding the mismatch between income poverty and deprivation: A dynamic comparative analysis. European Sociological Review, 20(4), 287-302.

Wilson, W. J. (1987). The truly disadvantaged: The inner city, the underclass, and public policy. Chicago: University of Chicago Press. 


\section{About the Authors}

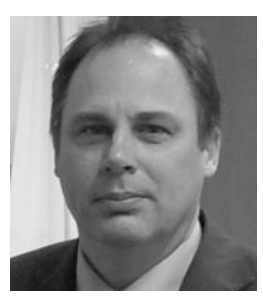

\section{Dr. J. Cok Vrooman}

J. Cok Vrooman is Head of the Labour and Public Services Research Sector at the Netherlands Institute for Social Research/SCP. He obtained a Masters Degree in Sociology from Erasmus University and $\mathrm{a}$ PhD in Sociology from Tilburg University, and was a board member of the Dutch Sociological Association. His main research interests are institutions, welfare regimes, social security, labour market, poverty, social exclusion and social inequality. Recent publications include Rules of Relief (2009), Regimes and cultures of social security (2012) and the annual Poverty Survey of the Netherlands.

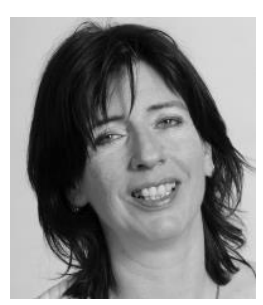

\section{Dr. Stella J. M. Hoff}

Stella Hoff studied Social Psychology at the University of Amsterdam and obtained her doctorate in 1995. Since 1997 she has been affiliated to the Netherlands Institute for Social Research|SCP, an independent scientific advisory body to the Dutch government. Her main research interests are poverty, social security and social exclusion.

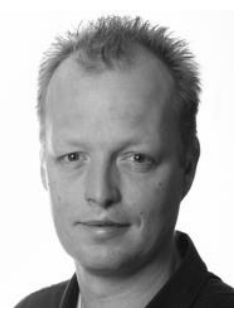

\section{Dr. Maurice Guiaux}

Maurice Guiaux is a researcher at the Knowledge Centre of the Dutch Institute for Employee Benefit Schemes (UWV). His fields of interest are social security and social policy. Formerly he was affiliated to the Netherlands Institute for Social Research|SCP, where he carried out research on poverty and social exclusion. His PhD thesis was concerned with loneliness and personal relationships. His current research focuses on household debt in relation to social security. 


\section{Appendices}

\section{Appendix A}

Survey items on social exclusion among children

\section{Inadequate social participation}

Items (brief description; response indicating exclusion in parentheses)

Takes part in a sport (no)

Takes part in sports activities organised by a community centre or the local council (no)

Takes swimming lessons (no, also not signed up)

Is a member of the Scouts (no)

Participates in activities through a church:

- church choir (no)

- altar boy (no)

- discussion group (no)

- Bible lessons (no)

- homework supervision (no)

- computer course (no)

- sports (no)

- other activities (no)

Participates in activities through a mosque:

- lessons in Arabic or Turkish language (no)

- lessons about Islam and the Koran (no)

- homework supervision (no)

- computer course (no)

- sports (no)

- other activities (no)

Takes music lessons (no)

Takes singing lessons (no)

Member of a choir (no)

Member of an orchestra (no)

Member of a music group or a rap group (no)

Participates in dancing, ballet or jazz dance (no)

Participates in street dancing (no)

Takes drawing or painting lessons or handicrafts (no)

Member of a drama club (no)

Member of a circus school (no)

Member of a draughts or chess club (no)

Member of a photography or cinema club (no)

Participates in school trips, excursions, outings (never)

Participates in after-school activities:

- homework class (no) ${ }^{a}$

- playing computer games or taking a computer course (no)

- sports (no)

- music (no)

- drama (no) 


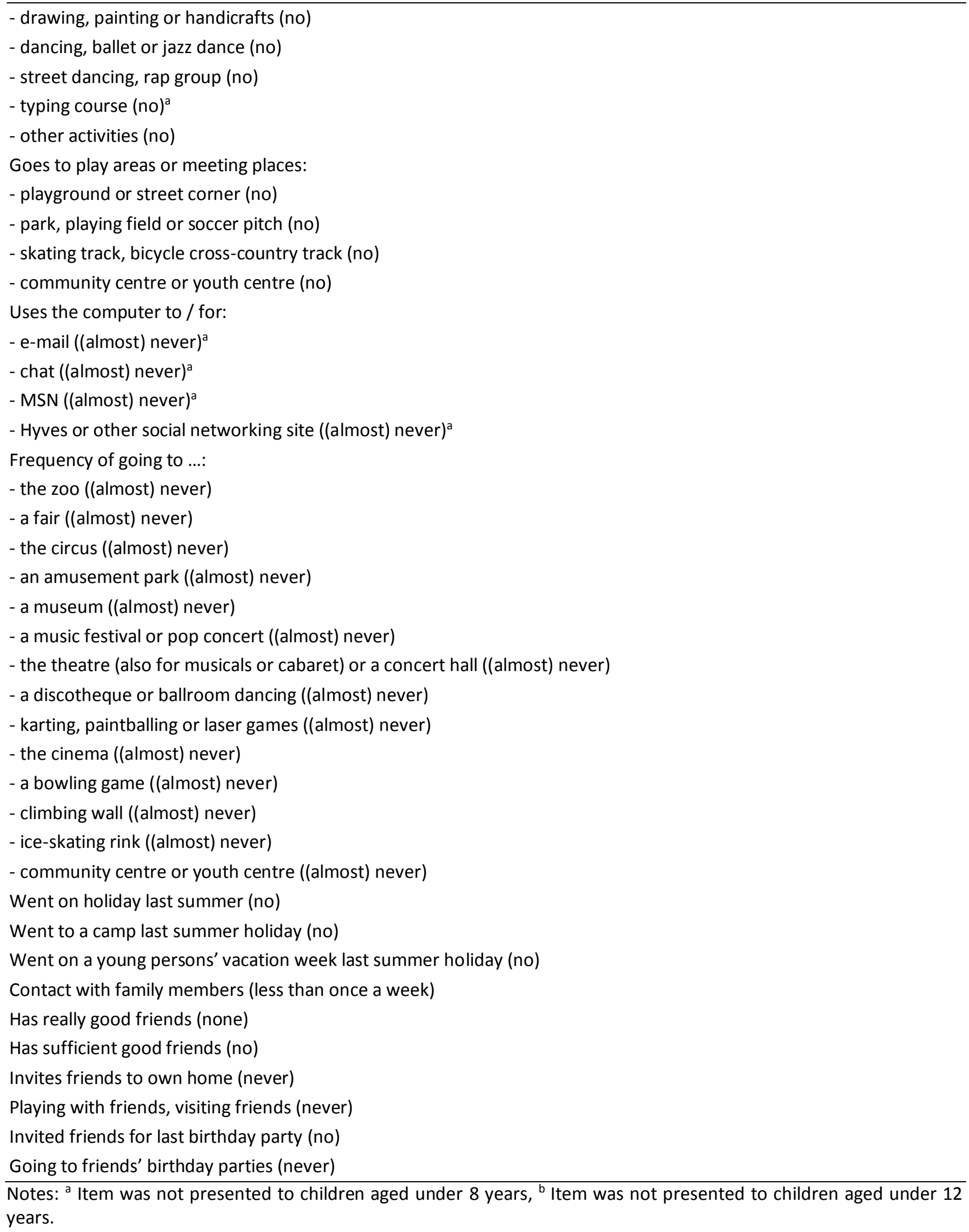


Inadequate normative integration

Items (brief description; response indicating exclusion in parentheses)

Bullying others (often)

Thinks that good school grades are important (not at all)

Suspended from school, sent home by way of punishment (often) ${ }^{a}$

Skipped school (yes, often) ${ }^{b}$

In the past 12 months:

- took things from a shop without paying (very often) ${ }^{\mathrm{b}}$

- applied graffiti to walls or bus shelters with paint or felt-tip pen (very often) ${ }^{b}$

- damaged road signs, lampposts or bus shelters (very often) ${ }^{b}$

- set fire to something on purpose (very often) $)^{b}$

- bought something knowing it was stolen (very often) ${ }^{b}$

- stole something from pupils or others at school (very often) ${ }^{\mathrm{b}}$

- stole money from parents' purse (very often) ${ }^{b}$

- committed burglary (very often) ${ }^{b}$

- threatened to beat up someone (very often) ${ }^{b}$

- beat someone up (very often) ${ }^{b}$

Notes: ${ }^{\mathrm{a}}$ Item was not presented to children aged under 8 years, ${ }^{\mathrm{b}}$ Item was not presented to children aged under 12 years.

\section{Inadequate access to basic social rights}

Items (brief description; response indicating exclusion in parentheses)

Sufficient play areas/meeting places in the neighbourhood (no)

Play areas/meeting places sufficiently safe (no)

Play areas/meeting places often damaged (yes)

Play areas/meeting places well-equipped (no)

Safe route to play areas/meeting places (no)

Play areas/meeting places kept clean (no)

Enough going on in the neighbourhood for children/youngsters (no)

Enjoys school (not at all)

People are bullied at school (yes, often)

People are bullied in the neighbourhood (yes, often)

Is bullied him/herself at school or in the neighbourhood (yes, often)

Has been rejected for a training course (yes, more than once) ${ }^{b}$

Has been rejected for trainee post (yes, more than once) ${ }^{b}$

Has been rejected for a (holiday) job (yes, more than once) ${ }^{b}$

Notes: ${ }^{\mathrm{a}}$ Item was not presented to children aged under 8 years, ${ }^{\mathrm{b}}$ Item was not presented to children aged under 12 years.

\section{Material deprivation}

Items (brief description; response indicating exclusion in parentheses)

Has a separate bedroom (no)

Has a bike of his/her own (no)

Has a suitable place to do homework (no)

Has a games computer of his/her own (no)

Has a mobile phone of his/her own (no)

Has an MP3 player (no)

Has an iPod (no)

Takes presents to friends' birthday parties (never)

Notes: ${ }^{a}$ Item was not presented to children aged under 8 years, ${ }^{b}$ Item was not presented to children aged under 12 years. 


\section{Appendix B}

Items in scales on social exclusion as a child (aged 8-12 years and 13-18 years, retrospective) and as an adult (aged 32-36 years)

Inadequate social participation of the parents when the child was 8-12 years old (retrospective)

Items (brief description)

Parents did not engage in voluntary work

Parents seldom or never went out

Parents seldom or never visited friends

Parents seldom or never invited friends to their home

Little or no diversity in contacts ${ }^{a}$

Note: ${ }^{a}$ The diversity in contacts reflects the level of engagement in voluntary work by the parents, going out, and visiting and inviting friends.

Material deprivation of the family when the child was 8-12 years old (retrospective)

Items (brief description)

Family did not go on holiday every year

The family situation was humble or poor

Family had to economise

Essential goods lacking in household ${ }^{a}$

Note: ${ }^{a}$ Of the following 13 items, at least seven were lacking: telephone, car, garage, washing machine, tumble dryer, dishwasher, refrigerator, camera, slide projector, television, piano, fireplace and central heating.

Inadequate social participation as a child aged 8-12 years (retrospective)

Items (brief description)

Did not take part in a sport

Was not a member of a sports or hobby club

(Almost) never went to the zoo, an amusement park, etc.

Had few or no good friends

Little or no diversity in contacts or activities ${ }^{a}$

Never invited friends to own home

Never visited friends

Never invited friends for birthday party

Note: ${ }^{\text {a }}$ The diversity in contacts reflects taking part in a sport, club membership, going on a trip, and having friends.

Inadequate social participation as a child aged $13-18$ years (retrospective)

Items (brief description)

Did not take part in a sport

Was not member of a sports or hobby club

(Almost) never went to the zoo, an amusement park, etc.

Had few or no good friends

Little or no diversity in contacts or activities ${ }^{a}$

Note: ${ }^{\text {a }}$ The diversity in contacts reflects taking part in a sport, club membership, going on a trip, and having friends. 
Material deprivation as a child aged 8-12 years (retrospective)

Items (brief description)

Did not have a separate bedroom

Did not have a bike of his/her own

Did not regularly get new clothes and shoes

Did not have suitable sports clothing

Did not take part in a sport or was not a member of a hobby club for financial reasons

Material deprivation as a child aged 13-18 years (retrospective)

Items (brief description)

Did not take part in a sport for financial reasons

Was not a member of a hobby club for financial reasons

Did not follow further education for financial reasons

Received less education than wished for because of the costs

Inadequate normative integration as a child aged 13-18 years (retrospective)

Items (brief description)

Regularly or often skipped school

Was sometimes suspended from school, sent home by way of punishment

Was suspended from school permanently

Committed burglary, bought a stolen item or stole from others

Applied graffiti to walls, damaged bus shelters or set fire to something in the street

Sometimes beat someone up or threatened to do so

Had several friends who were in trouble because of an addiction or criminal behaviour

Was (or a member of the household was) a police suspect

Appeared (or a member of the household appeared ) in court as a suspect

Inadequate access to basic social rights as a child aged 13-18 years (retrospective)

Items (brief description)

Unsafe upbringing: came into contact with child welfare work

Unsafe upbringing: came into contact with centre for child abuse

Unsafe upbringing: came into contact with Child Welfare Council

Neighbourhood where the family lived at age 13-18 had a bad reputation

Neighbourhood at age 13-18 had worse reputation than at age 8-12

Wanted more or different education

Education interrupted several times

Inadequate social participation as an adult (32-36 years old)

Items (brief description)

Does not engage in voluntary work

Is not member of a sports or hobby club

Rarely or never goes out

Rarely or never meets friends, family or co-workers in free time

Does not or not often go to church

Little or no diversity in contacts ${ }^{\mathrm{a}}$

Note: ${ }^{a}$ The diversity in contacts reflects the engagement in voluntary work, membership of a club, going out, frequency of contact with family, friends and co-workers, and going to church. 
Material deprivation as an adult (32-36 years old)

Items (brief description)

Difficulty making ends meet

Payment arrears

Insufficient income for basic needs (clothing, hot meals, a week's holiday, etc.)

Lacks items such as a car, dishwasher or computer for financial reasons

Unable to meet an unexpected but necessary purchase of 1,000 euros

Has been in contact with a municipal credit bank in the past five years

Inadequate normative integration as an adult (32-36 years old)

Items (brief description)

Thinks it is not important to work hard

Thinks it is not important to work in a precise and well-organised way

Thinks it is not important to be thrifty

Thinks it is not important to be honest

Does not agree that everybody who is able to should work

Thinks it is not important to do one's best at school

Thinks it is not important to complete your education

Agrees with living on benefit rather than having a job

Agrees that it is OK for people in receipt of social assistance benefit to moonlight

Inadequate access to basic social rights as an adult (32-36 years old)

Items (brief description)

Would like to move house within two years

Dissatisfied with home or residential environment

Feels unsafe at night in the neighbourhood

Experiences trouble from people living in the neighbourhood

People in the neighbourhood do not get on well

Neighbourhood has a bad reputation

Did not receive help from the authorities when asked for it

Has at times been rejected as a customer by a bank or mail order company

Social exclusion as an adult, general index (32-36 years old) ${ }^{\mathrm{a}}$

Items (brief description)

Inadequate social participation:

- is not a member of a sports or hobby club

- rarely or never goes out

- little or no diversity in contacts ${ }^{\mathrm{a}}$

Material deprivation:

- difficulty making ends meet

- payment arrears

- unsufficient income for basic needs (clothing, hot meals, a week's holiday, etc.)

- lacks items such as a car, dishwasher or computer for financial reasons

- unable to meet an unexpected but necessary purchase of 1,000 euros

Inadequate access to basic social rights:

- dissatisfied with home or residential environment

- people in the neighbourhood do not get on well

- neighbourhood has a bad reputation

- did not receive help from the authorities when asked for it

- has at times been rejected as a customer by a bank or mail order company

Note: ${ }^{a}$ The subscale on inadequate normative integration did not fit into the general index and was therefore not included. 


\section{Appendix C}

Standardised estimates of all model variables on social exclusion and being poor in adult life

\begin{tabular}{|c|c|c|}
\hline & Social exclusion as adult & Poor as adult \\
\hline & Bèta & Bèta \\
\hline \multicolumn{3}{|l|}{ Model variables depicted in the graph } \\
\hline Poor as child & 0.01 & 0.01 \\
\hline Material deprivation child & 0.09 & 0.07 \\
\hline Material deprivation parents & 0.07 & 0.06 \\
\hline Social participation child & 0.08 & 0.09 \\
\hline Social participation later youth (teenager) & 0.12 & 0.14 \\
\hline Health complaints child & -0.01 & -0.07 \\
\hline Health complaints later & -0.21 & -0.14 \\
\hline Subjective health & -0.11 & -0.07 \\
\hline Education & -0.32 & -0.34 \\
\hline $\begin{array}{l}\text { After age } 18 \text { periods of sickness, unemployment, } \\
\text { disability }\end{array}$ & 0.14 & 0.11 \\
\hline Currently benefit-dependent & 0.37 & 0.24 \\
\hline Currently in paid work & -0.03 & -0.43 \\
\hline Current income & 0.00 & -0.62 \\
\hline Education father & -0.11 & -0.13 \\
\hline Non-Western origin parents & 0.33 & 0.14 \\
\hline \multicolumn{3}{|l|}{ Model variables not depicted in the graph } \\
\hline Level of current job & -0.08 & 0.00 \\
\hline Has had multiple jobs since age 18 & 0.01 & 0.07 \\
\hline Satisfied with current job & -0.16 & 0.00 \\
\hline Education partner & -0.08 & -0.14 \\
\hline Partner has a job & -0.12 & -0.21 \\
\hline Father worked full-time & -0.02 & -0.01 \\
\hline Mother worked full-time & -0.01 & -0.01 \\
\hline Education mother & 0.01 & 0.01 \\
\hline Lived with both parents at age 8-12 & -0.04 & -0.02 \\
\hline Lived with both parents at age $13-18$ & -0.03 & -0.02 \\
\hline Family climate & -0.04 & 0.00 \\
\hline Parents encouraged reading & 0.00 & 0.00 \\
\hline Parents were involved in life of child & 0.01 & 0.01 \\
\hline Parents were interested in activities of child & -0.02 & -0.02 \\
\hline Child had good connection with father & 0.01 & 0.01 \\
\hline Child had good connection with mother & 0.02 & 0.02 \\
\hline Subjective health during childhood & -0.03 & -0.02 \\
\hline Health mother when respondent was aged 8-12 years & -0.03 & -0.01 \\
\hline Health father when respondent was aged 8-12 years & -0.01 & -0.02 \\
\hline Well-being as a child & -0.05 & 0.00 \\
\hline General state of mind & -0.17 & 0.00 \\
\hline
\end{tabular}

